\title{
Distribution pattern of antioxidants in white cabbage heads (Brassica oleracea L. var. capitata f. alba)
}

\author{
Michał Nosek $\cdot$ Ewa Surówka $\cdot$ Stanisław Cebula $\cdot$ \\ Andrzej Libik · Sylwia Goraj • Andrzej Kornas • \\ Zbigniew Miszalski
}

Received: 11 August 2010/Revised: 14 February 2011/Accepted: 28 March 2011/Published online: 1 May 2011

(C) The Author(s) 2011. This article is published with open access at Springerlink.com

\begin{abstract}
The aim of this paper has been to investigate the occurrence of health-promoting antioxidants, such as vitamins $\mathrm{C}$ and $\mathrm{E}$ as well as antioxidative enzymes, e.g. superoxide dismutase, catalase and peroxidase in different parts of the cabbage head (the outer one green leaves, the central leaf layer and the inner layer young, etiolated leaves). Vitamin C content in both the central $\left(209 \mathrm{mg} / \mathrm{dm}^{3}\right)$ and inner $\left(202 \mathrm{mg} / \mathrm{dm}^{3}\right)$ layers of cabbage heads was higher in comparison to the outer one $\left(163 \mathrm{mg} / \mathrm{dm}^{3}\right)$, while vitamin E content ( $\alpha$-tocopherol) in the outer layer $(4 \mu \mathrm{g} / \mathrm{g} \mathrm{FW})$ was higher by about 26 and $34 \%$ in comparison to the central and inner layers, respectively. The cooperation between vitamins and enzymatic antioxidants led to the highest $\mathrm{H}_{2} \mathrm{O}_{2}$ level in the outer layer, while the $\mathrm{O}_{2}^{--}$level was the highest in the inner part of the cabbage head. We conclude that leaf layers in cabbage heads reflect the different potential of bioactive compounds accumulation, related to the stage of tissue development, as well as tissue-specific stress response.
\end{abstract}

Communicated by H. Janska.

M. Nosek · S. Goraj · A. Kornas · Z. Miszalski Institute of Biology, Pedagogical University, ul. Podbrzezie 3, 31-054 Kraków, Poland

E. Surówka $(\bowtie) \cdot$ Z. Miszalski

Institute of Plant Physiology, Polish Academy of Sciences, ul. Niezapominajek 21, 30-239 Kraków, Poland

e-mail: surowka@ifr-pan.krakow.pl

S. Cebula $\cdot$ A. Libik

Department of Vegetable Crops and Horticulture Economics, Agricultural University, al. 29 Listopada 54,

31-425 Kraków, Poland
Keywords Vitamin C (ascorbate) · Vitamin E $(\alpha$-tocopherol) $\cdot$ Antioxidants $\cdot$ ROS $\cdot$ Brassica oleracea
Abbreviations
APX Ascorbate peroxidase
AsA L-Ascorbic acid
CAT Catalase
ROS Reactive oxygen species
SOD Superoxide dismutase

\section{Introduction}

The Brassicaceae family includes more than 350 genera and 3,500 species and is characterised by a short life cycle and wide adaptability. As such they are suited for cultivation in different seasons as well as in a variety of environments. Many Brassicaceae crops (e.g. cabbage, broccoli, Brussels sprouts, cauliflower), commonly known as crucifers, are recognised for their contribution to human nutrition (Salunkhe and Kadam 1998).

The white cabbage (Brassica oleracea L. var. capitata $\mathrm{f}$. $a l b a$ ), originating from the Mediterranean region, was known to the ancient Greeks and Romans. Today, due to consumer preferences and being cheap and available, it is among other crucifers one of the most important dietary vegetables consumed in Europe and in the world (Kusznierewicz et al. 2007). The white cabbage provides significant levels of vitamins (A, C, E, K), and other phytochemicals, such as glucosinolates or sulphur-containing compounds (Kurilich and Juvik 1999; Kopsell et al. 2004). Moreover, many epidemiological studies report a relationship between the consumption of Brassicaceae 
plants and protection against numerous chronic diseases, including several types of cancer (Byers and Perry 1992), cardio- and cerebrovascular, ocular and many neurological diseases (Block et al. 1992; Podsędek 2005). It is known that vitamins, such as vitamins $\mathrm{C}$ and $\mathrm{E}$ (Byers and Perry 1992; Cao et al. 1996; Singh et al. 2007) may stimulate the immune system and they can retard several degenerative processes (Hofius and Sonnewald 2003). Therefore, a more accurate characterisation of the content of these antioxidants in white cabbage is needed.

It is well established that antioxidants scavenge and regulate the level of reactive oxygen species (ROS) generated in metabolic processes and produced at a higher level under various stress conditions (Halliwell and Gutterridge 2007). Similarly to animals and humans, plant tissues enclose antioxidant systems including enzymatic (e.g. superoxide dismutase SOD, catalase CAT, ascorbate peroxidase APX) and non-enzymatic antioxidants, such as ascorbic acid (Asc, vitamin C) and tocopherols (vitamin E) (Mittler 2002). Antioxidants, such as vitamins $\mathrm{C}$ and $\mathrm{E}$, are essential for human and animal health, but they are synthesised only in photosynthetic organisms (Prior and Cao 2000; DellaPenna 2005). Vitamin C protects the hydrophilic space of the cell (Havaux et al. 2005), and acts as a photoprotective agent during photosynthesis, being involved in plant development and response of plant tissues against stress factors (Mittler 2002; Prior and Cao 2000; De Gara 2003; Smirnoff 2000; Kornas et al. 2010; Latowski et al. 2010). Alpha-tocopherol is the major vitamin $\mathrm{E}$ compound found in leaf chloroplasts, where it is located in the chloroplast envelope, thylakoid membranes and plastoglobuli. This antioxidant deactivates photosynthesis-derived ROS (mainly ${ }^{1} \mathrm{O}_{2}$ and $\mathrm{OH}$ ), and prevents the propagation of lipid peroxidation by scavenging lipid peroxyl radicals in thylakoid membranes (Kamal-Eldin and Appelqvist 1996). Vitamin C also plays an important role in the regeneration of $\alpha$-tocopheryl radicals produced during the reduction of lipid peroxyl radicals (Surówka et al. 2009; Mène-Saffrané and DellaPenna 2010).

Among enzymatic antioxidants, superoxide dismutase, catalase and peroxidases play a key role in the regulation of $\mathrm{O}_{2}^{--}$and $\mathrm{H}_{2} \mathrm{O}_{2}$ levels. SODs, found in almost all cellular compartments, disproportionate $\mathrm{O}_{2}^{--}$to $\mathrm{H}_{2} \mathrm{O}_{2}$ (Alscher et al. 2002). Hydrogen peroxide may be scavenged by catalases or peroxidases. CAT is mainly associated with peroxisomes where it scavenges $\mathrm{H}_{2} \mathrm{O}_{2}$ generated during photorespiration (Niewiadomska and Miszalski 2008; Passardi et al. 2005). Hydrogen peroxide may be also scavenged in the ascorbate-glutathione cycle, where in the first step of this pathway $\mathrm{H}_{2} \mathrm{O}_{2}$ is reduced to water by APX with the ascorbate as the electron donor (Asada 1999; Shigeoka et al. 2002).
The aim of this paper has been to study the distribution of vitamins $\mathrm{C}$ and $\mathrm{E}$ as well as activities of certain antioxidative enzymes, such as SODs, CATs and peroxidases, located in different white cabbage head layers. To our knowledge, this has been the first investigation of the occurrence of certain enzymatic and non-enzymatic antioxidants in different cabbage leaf layers and we have tried to correlate their levels or activity with some ROS compounds, such as $\mathrm{O}_{2}^{--}$or $\mathrm{H}_{2} \mathrm{O}_{2}$. The comparison of the distribution of primary antioxidants (vitamins) inside the cabbage head is interesting due to their bioactive properties and for nutritional and physiological aspects.

\section{Materials and methods}

\section{Plant material}

White cabbage seeds of the Counter $F_{1}$ cultivar were sown in a greenhouse to multipots filled with peat substrate. About 1 month old seedlings were planted into the field under natural environmental conditions near Kraków (in the southern part of Poland) and harvested in October. After 24-h adaptation to room conditions, leaves from three different layers of cabbage heads: outer (1st-3rd leaves), central (6th-8th leaves) and inner (14th-16th leaves) (Fig. 1) were frozen in liquid nitrogen and kept at $-70^{\circ} \mathrm{C}$ for further analysis. Analyses were performed on pooled material collected from appropriate leaves (outer, central and inner) of six cabbage heads.

\section{Standards and reagents}

3,3-diaminobenzidine tetrachloride (DAB) and nitroblue tetrazolium (NBT) staining reagents were prepared as solutions of 2 and $0.5 \mathrm{mg}$ per $\mathrm{mL}$ of potassium phosphate buffer, respectively. The titanium reagent was prepared as a 1:5(v/v) solution of titanium tetrachloride in concentrated $\mathrm{HCl}$. HPLC determination of vitamin E content was performed with use of $\alpha$-tocopherol standard. All reagents were provided by Sigma-Aldrich Chemie GmbH, Munich, Germany.

\section{Chlorophyll determination}

Chlorophyll $a+b$ content was determined using light absorption by aqueous acetone chlorophyll extracts (80\%) according to Arnon (1949). The tissue $(0.5 \mathrm{~g})$ was homogenised in chilled acetone $(1 \mathrm{~mL})$. After centrifugation at $14,000 \times g$ for $5 \mathrm{~min}$ at $4^{\circ} \mathrm{C}$ supernatant was collected. The concentrations of chlorophylls $a$ and $b$ were determined with a DU Beckman spectrophotometer at 663 and $645 \mathrm{~nm}$ using simultaneous equations based on the specific absorption coefficients for chlorophylls $a$ and $b$. 
Fig. 1 Indication of leaf layers: outer (light-exposed), central and inner taken for analysis from the white cabbage head (Brassica oleracea L. var. capitata f. alba)

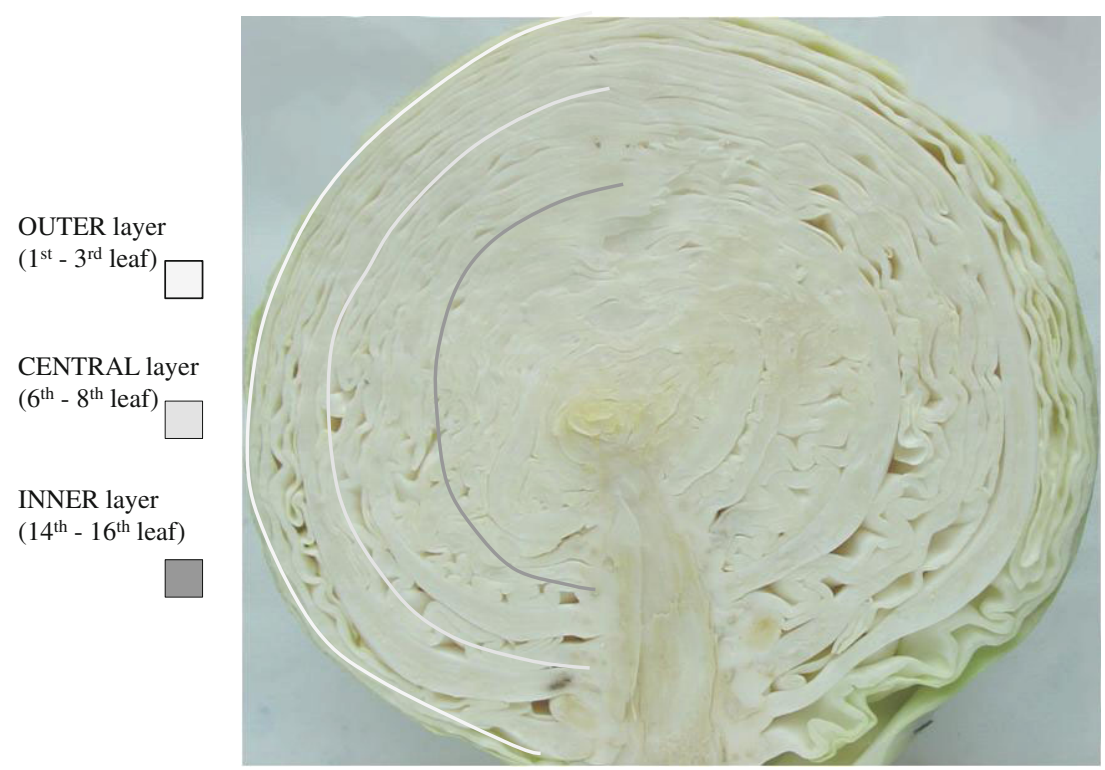

Extraction and determination of soluble proteins

The extraction of soluble proteins was completed in $100 \mathrm{mM}$ $\mathrm{pH} 8.0$ Tricine-Tris buffer containing $100 \mathrm{mM} \mathrm{MgSO}_{4}$, $1 \mathrm{mM}$ dithiotreitol (DTT) and $3 \mathrm{mM}$ EDTA. Leaves $(1.0 \mathrm{~g})$ were homogenised in $1.5 \mathrm{~mL}$ of the extraction buffer and centrifuged for $2 \mathrm{~min}$ at $12,000 \times \mathrm{g}$. The whole procedure was carried out at $4^{\circ} \mathrm{C}$. The level of soluble proteins was determined using the Bradford (1976) method.

The analysis of SOD isoforms and total peroxidase activity

The activity of SOD was estimated by the semi-quantitative polyacrylamide gel electrophoresis (PAGE) method. Gel staining was performed according to the protocol previously described by Miszalski et al. (1998). For each lane, $15 \mu \mathrm{g}$ of the protein extract was applied. For the identification of SOD isoforms, native gels were stained in buffers containing $5 \mathrm{mM} \mathrm{H} \mathrm{O}_{2}$ or $2 \mathrm{mM} \mathrm{KCN}$.

The total activity of peroxidases (POX) was estimated by the semi-quantitative method using PAGE, and the staining of the native gel was performed according to the protocol previously described by Barcelo et al. (1987). For each lane $30 \mu \mathrm{g}$ of protein was applied.

Gels were scanned and densitometric analyses were performed with Image J (GPL license).

Spectrophotometric measurements of antioxidant enzyme activities

Catalase (CAT) activity was measured according to the method described by Aebi (1984). The disappearance of 
hydrogen peroxide [initial concentration: $0.4 \% \mathrm{H}_{2} \mathrm{O}_{2}$ in phosphate buffer $\left(50 \mathrm{mM} \mathrm{KH} \mathrm{PO}_{4}, 50 \mathrm{mM} \mathrm{Na} \mathrm{HPO}_{4}, \mathrm{pH}\right.$ 7.0)] was monitored at $240 \mathrm{~nm}$. Enzyme activity was defined as $1 \mathrm{mmol}$ of $\mathrm{H}_{2} \mathrm{O}_{2}$ decomposed by $1 \mathrm{mg}$ of total soluble proteins per minute. For the calculation of the absorbance coefficient for $\mathrm{H}_{2} \mathrm{O}_{2}$ a value of 42.6 $(\mathrm{mmol} / \mathrm{L})^{-1} \mathrm{~cm}^{-1}$ was used.

Ascorbate peroxidase was measured spectrophotometrically according to Nakano and Asada (1981). Ascorbate peroxide activity was determined via the loss of the ascorbate level at a wavelength of $240 \mathrm{~nm}$ in a reaction mixture containing $\mathrm{pH} 7.0$ phosphate buffer $\left(\mathrm{KH}_{2} \mathrm{PO}_{4} /\right.$ $\mathrm{K}_{2} \mathrm{HPO}_{4}$ ), $1 \mathrm{mM}$ EDTA, $15 \mathrm{mM} \mathrm{L}$-AsA and $40 \mathrm{mM} \mathrm{H}_{2} \mathrm{O}_{2}$. Enzyme activity was defined as $1 \mathrm{mmol}$ of AsA decomposed by $1 \mathrm{mg}$ of protein per minute. For the calculation of the absorbance coefficient for AsA a value of 2.8 $(\mathrm{mmol} / \mathrm{L})^{-1} \mathrm{~cm}^{-1}$ was used.

\section{Vitamin $\mathrm{C}$ determination}

Cell sap from selected leaves was centrifuged for $15 \mathrm{~min}$ at $14,000 \times g$ and $4^{\circ} \mathrm{C}$. Ascorbate content in the cell sap was measured reflectometrically, using a Merck RQflex $10^{\odot}$ device. Ascorbic acid reduces yellow molybdophosphoric acid to phosphormolybdenum blue which is determined reflectometrically. Each experiment was conducted in three replicates.

Extraction of tocopherols and determination of $\alpha$-tocopherol content using an HPLC method

For the extraction of tocopherols, a modified method described by Heudi et al. (2004) was used. $5 \mathrm{~mL}$ of $96 \%$ $(v / v)$ ethanol was added to $0.5 \mathrm{~g}$ of powdered leaf tissue. Samples were incubated in a water bath at $70^{\circ} \mathrm{C}$. After 15 min incubation, $80 \%(w / v) \mathrm{KOH}$ solution was added and the samples were left in the water bath for the next $30 \mathrm{~min}$. After incubation, probes were centrifuged for $15 \mathrm{~min}$ at $4,000 \mathrm{~g}$ in $4^{\circ} \mathrm{C}$ and supernatant was mixed with water in 1:1 $(v / v)$ proportion and passed through XTR columns $\left(\right.$ Chromabond $\left.{ }^{\circledR}\right)$. The columns were rinsed twice with $25 \mathrm{~mL}$ of $N$-hexane which was then collected. The $N$-hexane from the samples was evaporated and the precipitate was dissolved in $1.5 \mathrm{~mL}$ of $96 \%$ methanol.

The separation of hydrophobic compounds was performed by HPLC using an Agilent 1100 apparatus. A $10 \mu \mathrm{L}$ sample was separated on a Zorbax Eclipse XBD C18 $4.6 \times 75 \mathrm{~mm} 3.5 \mu \mathrm{m}$ column. As a mobile phase, methanol (A) and acetonitrile/dichloromethane 1/1 $\mathrm{v} / \mathrm{v}$ (B) was used. Analysis was performed under a gradient of 0-4 min $100 \%$ A, 4-13 min 100-30\% A with $1 \mathrm{~mL} / \mathrm{min}$ flow rate. The eluate was analysed with a fluorescence detector with an excitation wavelength of $220 \mathrm{~nm}$ and emission wavelength of $333 \mathrm{~nm}$. Linearity was verified for $0-100 \mu \mathrm{g} / \mathrm{mL}$ of the test substance.

Statistical analysis

Two-way ANOVA followed by Tukey's HSD multiple range test was used to determine the individual treatment effects at $P \leq 0.05$.

\section{Results}

Chlorophyll and ROS compounds content

Moving from the outer towards the inner parts of cabbage heads (Fig. 1), their leaves differ in colour, morphology and, as shown on Fig. 2a, the total chlorophyll content decreases. The outer green leaves show the highest $\mathrm{H}_{2} \mathrm{O}_{2}$ level of about $12 \mu \mathrm{mol} \mathrm{H}_{2} \mathrm{O}_{2} / \mathrm{g} \mathrm{FW}$, approximately twofold higher than in the central and inner parts of cabbage heads (Fig. 2b, c), while the level of superoxide radicals was the highest in the inner layer (Fig. 2c). The veins of the leaf discs showed more intensive staining than interveined parts in both of the test ROS compounds (Fig. 2c).

\section{Activity of certain antioxidative enzymes}

In the leaves of white cabbage heads, five SOD isoforms were detected (Fig. 3b) and their activity pattern showed dependence on leaf layers (Fig. 3). In the inner layer, MnSOD activity was about $30 \%$ higher in comparison to the outer and central layers (Fig. 3a). An FeSOD isoform was identified only in the outer layer. Three CuZnSOD isoforms (CuZnSODI, CuZnSODII, CuZnSODIII) were found. CuZnSODIII activity gradually decreased from the outer to the inner layers, while those of CuZnSODI and CuZnSODII were identified only in central and inner layers (Fig. 3a). Their activities were higher in the inner than in the outer layer. The highest CuZnSODIII activity coincides with the high level of total chlorophyll in green leaves, as well as with the highest $\mathrm{H}_{2} \mathrm{O}_{2}$ level (Figs. 2a, b, 3a).

The analysis of total peroxidase activity was similar to APX activity with a gradual loss from the outer to the inner layers (Figs. 4, 5b). In contrast to this, the highest APX activity at a level of $205 \mu \mathrm{mol}$ AsA reduced/min/mg protein in the outer layer was determined and it was about fivefold higher than in central and in inner layers (Fig. 5b). Both the outer and inner layers of cabbage heads showed similar catalase activity $\left(10.8\right.$ and $9.55 \mu \mathrm{mol} \mathrm{H}_{2} \mathrm{O}_{2}$ decomposed/min/mg protein, respectively), and higher than that measured in the central layer $\left(4.56 \mu \mathrm{mol} \mathrm{H}_{2} \mathrm{O}_{2}\right.$ decomposed/min/mg protein; Fig. 5a). 
Fig. 2 Level of chlorophyll (Chl) and ROS compounds in cabbage leaves (Brassica oleracea L. var. capitata f. alba). Total chlorophyll $(a+b)$ (a); hydrogen peroxide content (b); values represent means $\pm \mathrm{SD}(n=3)$. The same letters above bars indicate no differences at the significance level $(P \leq 0.05)$, according to the Tukey HSD (high significant differences) test. Detection of superoxide radicals and hydrogen peroxide in leaf discs $(\varnothing=12 \mathrm{~mm})$ of cabbage heads using NBT or DAB staining, respectively (c). No specific coloration was observed in parallel controls

\section{Content of low molecular antioxidants}

Vitamin $\mathrm{C}$ showed a higher content in both central $(209 \mathrm{mg} / \mathrm{L})$ and inner $(202 \mathrm{mg} / \mathrm{L})$ layers of the cabbage head, in comparison to the outer leaf $(163 \mathrm{mg} / \mathrm{L})$ (Fig. $5 \mathrm{c})$. The content of vitamin $\mathrm{E}(\alpha$-tocopherol) measured in the outer layer was higher by about 26 and 30\%, respectively, in comparison to the central and inner layers (Fig. 5d).

\section{Discussion}

The outer leaves of cabbage heads contain chlorophyll (Chl), which allows them to perform photosynthesis (Solymosi et al. 2005). The foliar concentration of the photosynthetic pigments is related to the amount of absorbed solar radiation in the PhAR range (Curran et al. 1990). Towards the inner part of the cabbage head, leaves are etiolated due to the limited light access (Kruk 2005). As shown by Mittler (2002) photosynthesis as well as other metabolic processes, such as photorespiration or respiration, can lead to the generation of excess ROS and oxidative stress. Our results indicate that in the white cabbage head the production/removal of superoxide radicals and hydrogen peroxide is leaf layer dependent, and photosynthetically competent tissues are the most important source of $\mathrm{H}_{2} \mathrm{O}_{2}$ (Fig. 2). According to Shao et al. (2008) superoxide radicals $\left(\mathrm{O}_{2}^{--}\right)$and hydrogen peroxide $\left(\mathrm{H}_{2} \mathrm{O}_{2}\right)$ act as secondary messengers in many processes associated with plant metabolism and development; thus, we suppose that the high $\mathrm{H}_{2} \mathrm{O}_{2}$ level in the outer layer and the superoxide radical level in the inner layer (Fig. 2b, c) may be primarily related to the stage of tissue development and to the type and level of ROS molecules needed for ROS-related signal induction.

The excess of ROS in plant cells is scavenged with enzymatic (SODs, catalases, APXs) and non-enzymatic (vitamins E and C) antioxidants (Havaux et al. 2005; Hofius et al. 2004; Munné-Bosch and Peńuelas 2005). The first line of cell defence against ROS is SODs classified into three groups: iron SOD (FeSOD), manganese SOD (MnSOD) and copper-zinc SOD (CuZnSOD) (Alscher et al. 2002). In B. oleracea, we identified five forms of SODs (Fig. 3) and the activity of FeSOD was identified

\section{A}

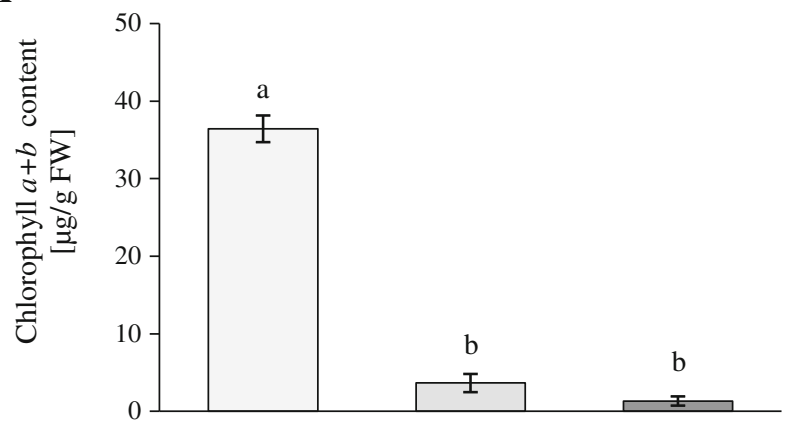

B

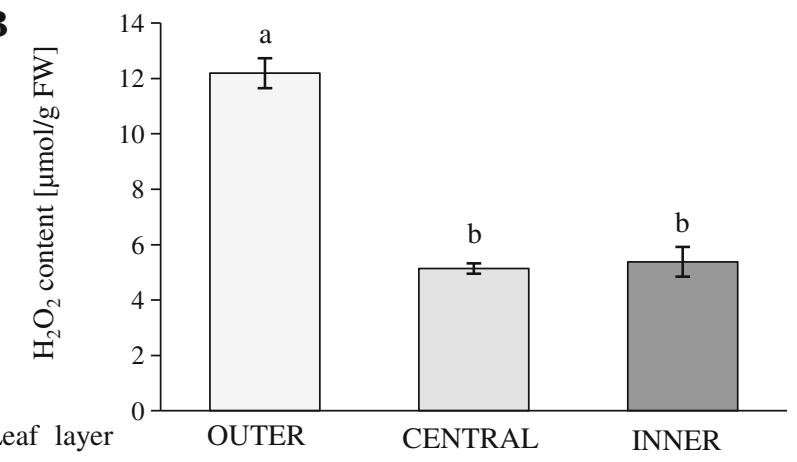

C
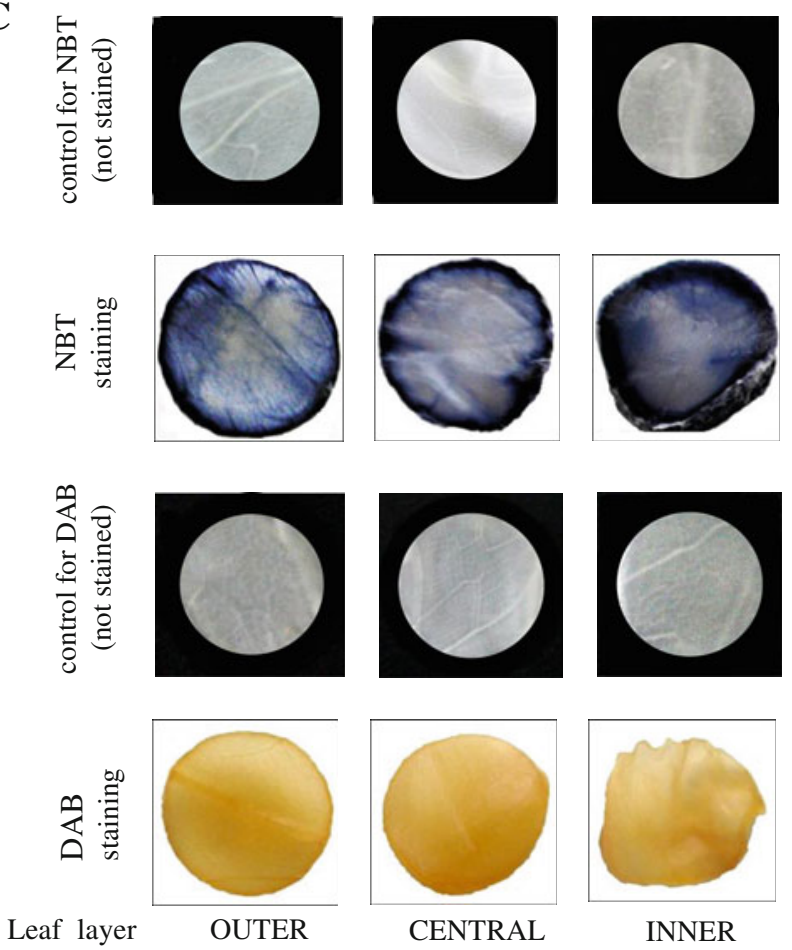

CENTRAL

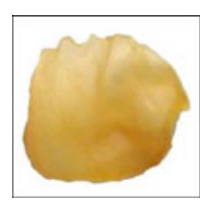

INNER

only in the layer of green leaves. These data are in agreement with Alscher et al. (2002) indicating mainly chloroplastic localisation of the FeSOD form. Moreover, our results lead to the suggestion that CuZnSODIII is also associated with chloroplasts (Fig. 3), while the other two 
A

\begin{tabular}{|l|c|c|c|}
\cline { 2 - 4 } \multicolumn{1}{c|}{} & \multicolumn{3}{c|}{ Activity of SOD forms [AU] } \\
\hline SOD form leaf layer & OUTER & CENTRAL & INNER \\
\hline MnSOD & $15.1 \pm 1.39$ & $16.8 \pm 1.76$ & $22.9 \pm 1.31$ \\
\hline FeSOD & $3.8 \pm 0.2$ & - & - \\
\hline CuZnSODI & - & $1.7 \pm 0.16$ & $4.4 \pm 0.14$ \\
\hline CuZnSODII & - & $2.5 \pm 0.3$ & $3.7 \pm 0.14$ \\
\hline CuZnSODIII & $5.1 \pm 0.53$ & $4.8 \pm 0.09$ & $4.0 \pm 0.17$ \\
\hline
\end{tabular}

B

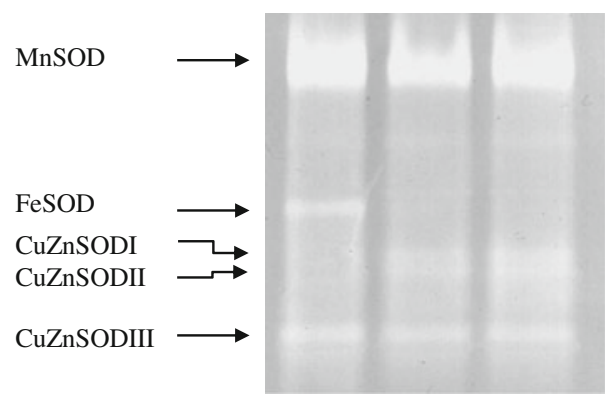

Fig. 3 PAGE activity staining of superoxide dismutase (SOD) isoforms in leaf extracts of Brassica oleracea cv. capitata. Extracts of soluble proteins containing $15.0 \mu \mathrm{g}$ protein were loaded to each well. The gel shown is a typical example of three replicates. The area

\begin{tabular}{|c|c|c|c|}
\hline leaf layer & OUTER & CENTRAL & INNER \\
\hline Total POX activity [AU] & $70.9 \pm 5.5$ & $59.1 \pm 5.2$ & $46.7 \pm 3.1$ \\
\hline & & & \\
\hline
\end{tabular}

Fig. 4 Peroxidases visualized on native polyacrylamide gels stained with 3,3-diaminobenzidine (DAB). Extracts of soluble proteins containing $30.0 \mu \mathrm{g}$ protein were loaded to each well. The gel shown is a typical example of three replicates

CuZnSODs isoforms (CuZnSODI and CuZnSODII) with the highest activity in central and inner layers (Fig. 3a) are more related to processes occurring outside the chloroplasts. The highest activity of the CuZnSODI and $\mathrm{Cu}-$ ZnSODII isoforms in the inner leaves corresponds to the highest level of superoxide radicals and the highest MnSOD activity (Figs. 2, 3a) localised mainly in mitochondria (Alscher et al. 2002). We associate these alterations in antioxidative enzyme activity and superoxide

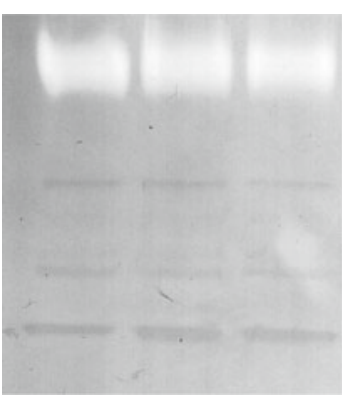

$5 \mathrm{mM} \mathrm{H}_{2} \mathrm{O}_{2}$

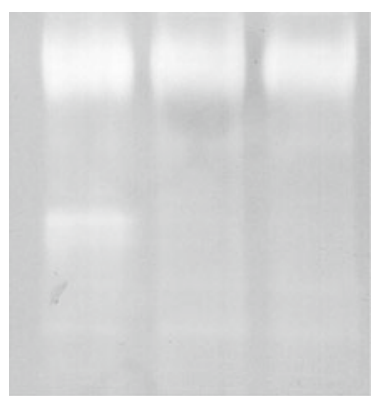

$2 \mathrm{mM} \mathrm{KCN}$ corresponding to the sum of activities included inside the defined peak of the SOD isoform is presented as mean \pm SD (a). Identification of SOD forms stained with nitroblue tetrazolium (NBT) in the presence of $5 \mathrm{mM} \mathrm{H}_{2} \mathrm{O}_{2}$ or $2 \mathrm{mM} \mathrm{KCN} \mathrm{(b)}$

radical level with vigorous respiratory processes in developing leaves inside the cabbage head. These data are in agreement with Azcón-Bieto (1983), showing that respiratory activity in young leaves is higher than in mature tissues, and with Lennon et al. (1995) who presented a general decline of respiration with age and with the development of photosynthetic activity.

The concentration of hydrogen peroxide may be regulated by catalases and peroxidases. As suggested by Mittler (2002), CAT might be involved in the removal of excess ROSs, while APX is probably responsible for the modulation of the ROS level for signalling purposes, since they have different affinities for $\mathrm{H}_{2} \mathrm{O}_{2}$ (CAT at $\mathrm{mM}$ and APX at $\mu \mathrm{M}$ range). In the experiments we point out that in green leaves of cabbage heads the $\mathrm{H}_{2} \mathrm{O}_{2}$ content (Fig. 2b) in comparison to interior layers was also the highest, parallel to the high catalase activity (Fig. 5a) as well as the highest total peroxidase (Fig. 4) and APX activities (Fig. 5b). These results indicate that different enzymatic antioxidants are involved in the regulation of $\mathrm{H}_{2} \mathrm{O}_{2}$ concentration in different leaf layers and the $\mathrm{H}_{2} \mathrm{O}_{2}$ level is dependent on the part of leaves in the cabbage head. Since the higher $\mathrm{H}_{2} \mathrm{O}_{2}$ content was measured in chlorophyll-rich leaves, it could 
A
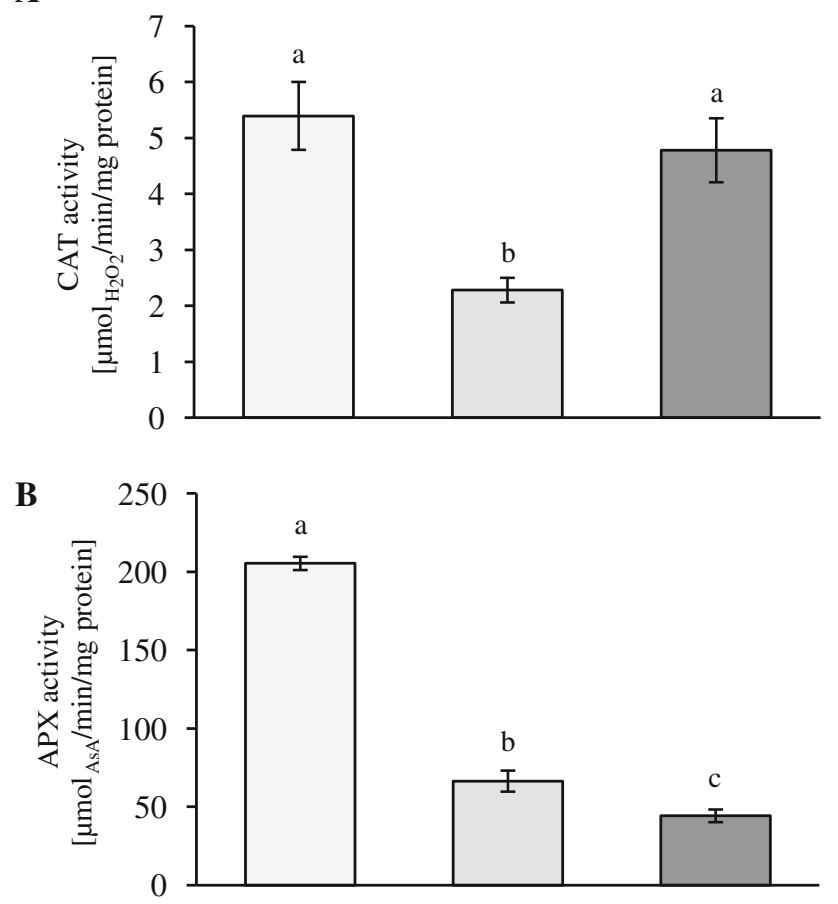

C

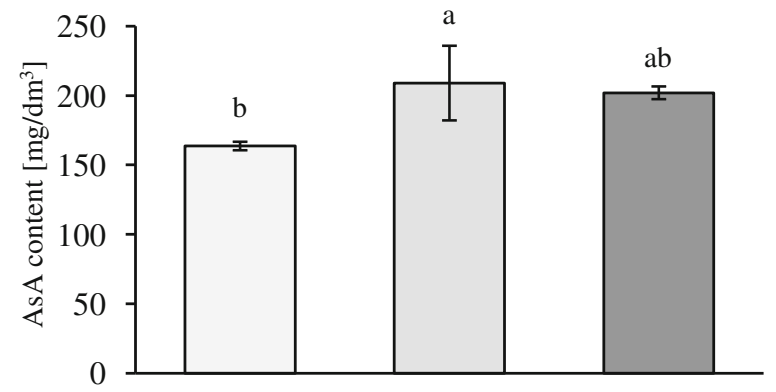

D

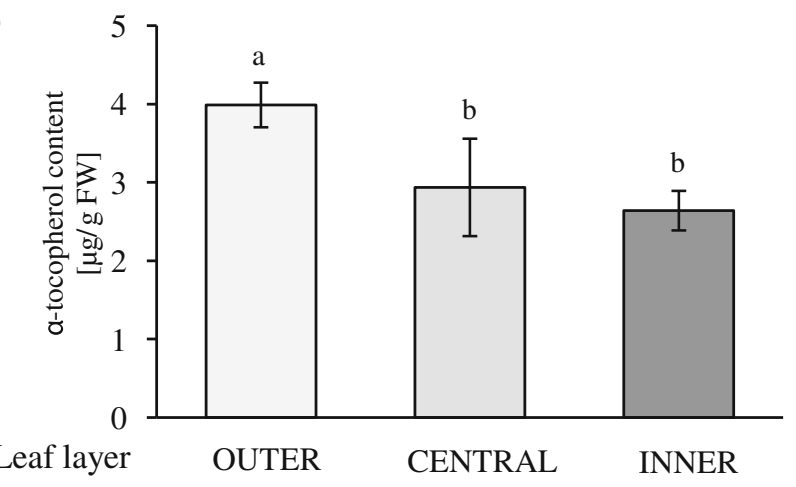

Fig. 5 Activity of catalase (a), ascorbate peroxidase (b) and content of low molecular antioxidants-vitamin C (c) and vitamin $\mathrm{E}(\mathbf{d})$ in Brassica oleracea cv. capitata leaves. Values represent mean $\pm \mathrm{SD}$ $(n=3)$. The same letters above bars indicate no differences at the significance level $(P \leq 0.05)$, according to the Tukey HSD (high significant differences) test

be speculated that the $\mathrm{H}_{2} \mathrm{O}_{2}$ generated during photosynthesis acts as signalling molecules and plays a crucial role in the control of metabolic and defence processes in cabbage heads. It is also worthy to note that in the light- exposed layer, APX activity was nearly twice as high as in the etiolated leaf layers (Fig. 5b) and parallel to the lowest vitamin $\mathrm{C}$ content (Fig. 5b, c). This indicates that APX is strongly involved in the control of the $\mathrm{H}_{2} \mathrm{O}_{2}$ level generated in photosynthetic and photorespiratory processes in the chlorophyll rich layer, and the rapid induction of APX in intense light could compensate the slow response of the ascorbate pool itself, as previously shown by Foyer and Noctor (1999).

In the inner part of cabbage heads, the relatively high activity of total peroxidises peroxidases and catalases (Figs. 4, 5a) and a similarly lower $\mathrm{H}_{2} \mathrm{O}_{2}$ level in comparison to the outer layer (Fig. 2b, c) lead to a conclusion that in etiolated leaves $\mathrm{H}_{2} \mathrm{O}_{2}$ is removed with higher efficiency and peroxidases may play a regulatory role in the regulation of $\mathrm{H}_{2} \mathrm{O}_{2}$ content. It seems that peroxidases in the inner part may be involved in the regulation of tissue growth and development of e.g. cell elongation. In the etiolated part of cabbage heads, APX activities are probably potentially inhibited by ascorbate (Figs. 4, 5c), as previously shown by Cordoba-Pedregosa et al. (1996) in experiments made on onions.

The significant alteration of antioxidative enzyme activities (CAT, APX and SOD) measured in different leaf layers is probably related to the changes in non-enzymatic antioxidant content. Our results point out that in the white cabbage head vitamins $\mathrm{C}$ and $\mathrm{E}$ are located in different proportions in outer, central and inner layers (Fig. 5c, d) and this is probably related to the metabolic state of leaves as well as to the functions of these compounds in metabolic processes as well as in antioxidative defence. Since vitamins $\mathrm{C}$ and $\mathrm{E}$ are part of information-rich redox buffers and enzymatic cofactors (Foyer 2005), they may play an important role in redox cell signalling, they may regulate gene expression and influence tissue growth. As demonstrated by Smirnoff and Pallanca (1996), vitamin C may accumulate at high concentrations in photosynthetic tissues, in which it is intimately involved in the regulation of photosynthesis and protection of chloroplasts against damage caused by ROS, such as $\mathrm{O}_{2}^{--}, \mathrm{H}_{2} \mathrm{O}_{2}$, hydroxyl radicals $(\mathrm{OH})$ and singlet oxygen $\left({ }^{1} \mathrm{O}_{2}\right)$. In contrast to this, our results indicate an about $25 \%$ decrease in vitamin $\mathrm{C}$ content in the green layer in comparison to the interior parts of cabbage heads (Fig. 5c). This may be due the involvement of vitamin $\mathrm{C}$ in many protective processes. Vitamin $\mathrm{C}$ may be used up in the ascorbate-glutathione cycle and act as a co-factor of violaxanthin de-epoxidase in the xanthophyll cycle; it may also be used up for vitamin $\mathrm{E}$ regeneration (Müller-Moulé et al. 2002). However, in inner layers the high content of ascorbate similar to the high activities of MnSOD, CuZnSODI and CuZnSODII as well the high level of superoxide radicals (Figs. 2c, 3a, 5c) seem to be related to the very active metabolism in young tissues 
Fig. 6 HPLC chromatograms of tocopherol standards and extracts of Brassica oleracea leaves. Other details are given in "Materials and methods"

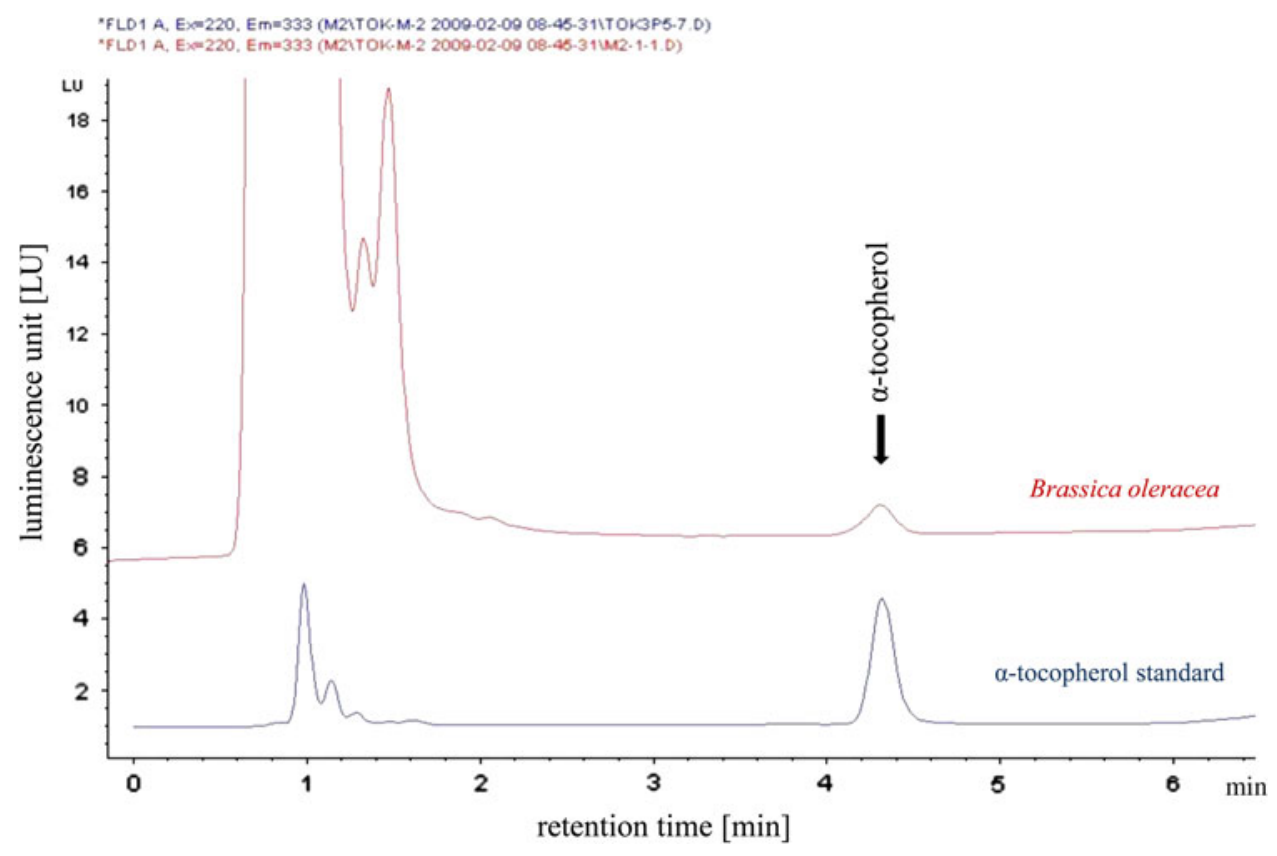

and plant growth processes, such as cell division and cell elongation, as demonstrated earlier on an Arabidopsis vtc- 1 mutant by Veljovic-Jovanovic et al. (2001). Our results are also in agreement with earlier data (De Gara et al. 1991, 1996; Borraccino et al. 1994; Lennon et al. 1995) showing that developing tissues have higher mitochondrial activity/ amount as well as a higher vitamin $\mathrm{C}$ level than mature tissues.

The most extensively described function of $\alpha$-tocopherol is its involvement in various mechanisms of the protection of chloroplast membranes and polyunsaturated fatty acids against ROS (especially singlet oxygen) action (Maeda and DellaPenna 2007; Mène-Saffrané and DellaPenna 2010). Our results show that $B$. oleracea leaves have a relatively low content of total $\alpha$-tocopherol when compared with leaves of other species (Szymańska and Kruk 2008a, b). Moreover, the distribution pattern of $\alpha$-tocopherol found in white cabbage head leaves is rather different than that in lettuce heads showing the lowest concentration of $\alpha$-tocopherol in the intermediate part (Szymańska and Kruk 2008a). Our results (Figs. 5d, 6) point out that the occurrence of vitamin $\mathrm{E}$ is not restricted only to green leaves. Vitamin $\mathrm{E}$ is also localised in etiolated parts of cabbage heads and these results are in agreement with Szymańska and Kruk (2008a) showing localisation of $\alpha$-tocopherol in different parts of lettuce heads. Moreover, our results indicate the highest $\alpha$-tocopherol content in the outer leaves (Fig. 5d). Such localisation of vitamin E may be due to the organelles in which it is synthesised, such as chloroplasts and chromoplasts, as shown by Horvath et al. (2006). Moreover, our results point out that the dietary properties of the investigated parts of cabbage heads are different.

\section{Conclusions}

The synchronization of antioxidative processes occurring in cabbage leaves (among outer, central and inner layers) lead to different levels and types of ROS in tissues at different stages of their development and physiological functions. Moreover, cabbage head leaves represent heterogeneity of the biological material.

The alteration of vitamins $\mathrm{C}$ and $\mathrm{E}$ content inside the cabbage head suggests that they play not only an antioxidative role and they may be somehow involved in metabolic regulation and/or plant signalling.

The significant variations in vitamins $\mathrm{C}$ and $\mathrm{E}$ levels among the different leaf layers are responsible for differences in the health-promoting properties of cabbage head leaf layers. This suggests differentiated utilisation of these parts of cabbage heads by consumers according to their demand.

Acknowledgments This work was supported by the Polish Committee for Scientific Research (project No. R120452), Polish Ministry of Science and Higher Education (project No. N N310 298 639), the Deutscher Akademischer Austauschdienst (DAAD) and Alexander von Humboldt Foundation (AvH).

Open Access This article is distributed under the terms of the Creative Commons Attribution Noncommercial License which permits any noncommercial use, distribution, and reproduction in any medium, provided the original author(s) and source are credited.

\section{References}

Aebi H (1984) Catalase in vitro. Methods Enzymol 105:121-126 
Alscher RG, Erturk N, Heath L (2002) Role of superoxide dismutases (SODs) in controlling oxidative stress in plants. J Exp Bot 53:1331-1341

Arnon DI (1949) Cooper enzymes in isolated chloroplasts. Polyphenoloxidase in Beta vulgaris. Plant Physiol 24:1-15

Asada K (1999) The water-water cycle in chloroplasts: scavenging of active oxygen and dissipation of excess photons. Annu Rev Plant Physiol Plant Mol Biol 50:601-639

Azcón-Bieto J (1983) Inhibition of photosynthesis by carbohydrates in wheat leaves. Plant Physiol 73:681-686

Barcelo R, Munoz R, Sabater F (1987) Lupin peroxidase: isolation and characterization of cell wall-bound isoperoxidase activity. Physiol Plant 71:448-454

Block G, Patterson B, Subhar A (1992) Fruit, vegetables and cancer prevention: a review of the epidemiological evidence. Nutr Cancer 18:1-29

Borraccino G, Mastropasqua L, de Leonardis S, Dipierro S (1994) The role of the ascorbic acid system delaying the senscence of oat (Avena sativa L.) leaf segments. J Plant Physiol 2:161-166

Bradford M (1976) A rapid and sensitive method for the quantitation of microgram quantities of protein utilizing the principle of protein-dye binding. Anal Biochem 72:248-254

Byers T, Perry G (1992) Dietary carotenes, vitamin C, and vitamin E as protective antioxidants in human cancers. Ann Rev Nutr 12:139-159

Cao G, Sofic E, Prior R-L (1996) Antioxidant capacity of tea and common vegetables. J Agric Food Chem 44:3426-3431

Cordoba-Pedregosa M, Gonzalez-Reyes JA, Canadillas M, Navas P, Cordoba F (1996) Role of apoplastic and cell-wall peroxidases on the stimulation of root elongation by ascorbate. Plant Physiol 3:1119-1125

Curran PJ, Duncan JL, Gholz HL (1990) Exploring the relationship between reflectance read edge and chlorophyll content in slash pine. Tree Physiol 7:33-48

De Gara L (2003) Ascorbate metabolism and plant growth: from germination to cell death. In: Asard H, Smirnoff J, May N (eds) Vitamin C: its function and biochemistry in animals and plants. Bios Scientific Publishers Ltd, Oxford, pp 83-95

De Gara L, Paciolla C, Liso R, Stefani A, Arrigoni O (1991) Correlation between ascorbate peroxidase and some anomalies of seedlings from aged caryopses of Dasypyrum villosum (L.) Borb. J Plant Physiol 137:697-700

De Gara L, de Pinto MC, Paciolla C, Cappetti V, Arrigoni O (1996) Is ascorbate peroxidase only a scavenger of hydrogen peroxide? In: Obinger C, Burner O, Ederman R, Penel C, Greppen H (eds) Plant peroxidases: biochemistry and physiology. University of Geneva, Geneva, pp 157-162

DellaPenna D (2005) A decade of progress in understanding vitamin E synthesis in plants. J Plant Physiol 162:729-737

Foyer C (2005) Redox homeostasis and antioxidant signaling: a metabolic interface between stress perception and physiological responses. Plant Cell 17:1866-1875

Foyer C, Noctor G (1999) Leaves in dark see the light. Science 284:599-601

Fryer MJ, Oxborough K, Mullineaux PM, Baker NR (2002) Imaging of photo-oxidative stress response in leaves. J Exp Bot 372:1249-1254

Halliwell B, Gutterridge JMC (2007) Free radicals in biology and medicine, 4th edn. Oxford University Press, USA

Havaux M, Eymery F, Porfirova S, Rey P, Dörmann P (2005) Vitamin E protects against photoinhibition and photooxidative stress in Arabidopsis thaliana. Plant Cell 17:3451-3469

Heudi O, Trisconi MJ, Blake CH (2004) Simultaneous quantification of vitamins $\mathrm{A}, \mathrm{D} 3$ and $\mathrm{E}$ in fortified infant formulae by liquid chromatography-mass spectrometry. J Chromatogr A 1022:115-123
Hofius D, Sonnewald U (2003) Vitamin E biosynthesis: biochemistry meets cell biology. Trends Plant Sci 8:6-8

Hofius D, Hajirezaei M, Geiger $M$, Tschiersch $H$, Melzer $M$, Sonnewald U (2004) RNAi-mediated tocopherol deficiency impairs photoassimilate export in transgenic potato plants. Plant Physiol 135:1256-1268

Horvath G, Wessjohann L, Bigirimana J, Jansen M, Guisez Y, Caubergs R, Horemans N (2006) Differential distribution of tocopherols and tocotrienols in photosynthetic and non-photosynthetic tissues. Phytochemistry 12:1185-1195

Kamal-Eldin A, Appelqvist LA (1996) The chemistry and antioxidant properties of tocopherols and tocotrienols. Lipids 31:671-701

Kopsell DA, Kopsell DE, Lefsrud MG, Curran-Cellentano J, Dukach L (2004) Variation in lutein, $\beta$-carotene, and chlorophyll concentrations among Brassica oleracea cultigens and seasons. Hortic Sci 39:361-364

Kornas A, Kuźniak E, Ślesak I, Miszalski Z (2010) The key role of the redox status in regulation of metabolism in photosynthesizing organisms. Acta Biochim Pol 57:143-151

Kruk J (2005) Occurrence of chlorophyll precursors in leaves of cabbage heads - the case of natural etiolation. J Photochem Photobiol B Biol 80:187-194

Kurilich AC, Juvik J (1999) Quantification of carotenoid and tocopherol antioxidants in Zea mays. J Agric Food Chem 47:1948-1955

Kusznierewicz B, Bartoszek A, Wolska L, Drzewiecki J, Gorinstein S, Namieśnik J (2007) Partial characterization of white cabbages (Brassica oleracea var. capitata f. alba) from different regions by glucosinolates, bioactive compounds, total antioxidant activities and proteins. LWT Food Sci Tech 41:1-9

Latowski D, Surówka E, Strzałka K (2010) Regulatory role of components of ascorbate-glutathione pathway in plant stress tolerance. In: Naser A, Shahid U, Ming-Tsair Ch (eds) Ascorbate-glutathione pathway and stress tolerance in plants. Springer, Berlin, pp 1-54

Lennon AM, Pratt J, Leach G, Moore AL (1995) Developmental regulation of respiratory activity in pea leaves. Plant Physiol 107:925-932

Maeda H, DellaPenna D (2007) Tocopherol functions in photosynthetic organisms. Curr Opin Plant Biol 10:260-265

Mène-Saffrané L, DellaPenna D (2010) Biosynthesis, regulation and functions of tocochromanols in plants. Plant Physiol Biochem 48:301-309

Miszalski Z, Ślesak I, Niewiadomska E, Bączek R, Lüttge U, Ratajczak R (1998) Subcellular localization and stress responses of superoxide dismutase isoforms from leaves in the $\mathrm{C}_{3}$-CAM intermediate halophyte Mesembryanthemum crystallinum L. Plant Cell Environ 21:169-179

Mittler R (2002) Oxidative stress, anitoxidants and stress tolerance. Trends Plant Sci 9:405-410

Müller-Moulé P, Conklin PL, Niyogi KK (2002) Ascorbate deficiency can limit violaxanthin de-epoxidase activity in vivo. Plant Physiol 128:970-977

Munné-Bosch S, Peńuelas J (2005) Isoprenoids: an evolutionary pool for photoprotection. Trends Plant Sci 10:166-169

Nakano Y, Asada K (1981) Hydrogen peroxide is scavenged by ascorbate-specific peroxidase in spinach chloroplasts. Plant Cell Physiol 5:867-880

Niewiadomska E, Miszalski Z (2008) Partial characterization and expression of leaf catalase in the CAM-inducible halophyte in Mesembryanthemum crystallinum L. leaves. Plant Physiol Biochem 4:421-427

Noctor G, Foyer C (1998) Ascorbate and glutatione: keeping active oxygen under control. Annu Rev Plant Physiol Plant Mol Biol 49:249-279 
Passardi F, Cosio C, Penel C, Dunand C (2005) Peroxidases have more function than a Swiss army knife. Plant Cell Rep 24:255-265

Podsędek A (2005) Natural antioxidants and antioxidant capacity of Brassica vegetables: a review. Food Sci Technol 40:1-11

Prior RL, Cao G (2000) Antioxidant phytochemicals in fruits and vegetables: diet and health implications. Hortic Sci 35:588-592

Salunkhe DK, Kadam SS (1998) Handbook of vegetable science and technology: production, composition, storage, and processing. Marcel Dekker Inc., New York

Shao H, Chu L, Lu Z, Kang C (2008) Primary antioxidant free radical scavenging and redox signaling pathways in higher plants. Int $\mathrm{J}$ Biol Sci 4:8-14

Shigeoka S, Ishikawa T, Tamoi M, Yoshiko M, Takeda T, Yabata Y, Yoshimura K (2002) Regulation and function of ascorbate peroxidase isoenzymes. J Exp Bot 372:1305-1319

Singh J, Upadhyay AK, Prasad K, Bahadur A, Rai M (2007) Variability of carotenes, vitamin C, E and phenolics in Brassica vegetables. J Food Comp Anal 20:106-112

Ślesak I, Ślesak H, Libik M, Miszalski Z (2008) Antioxidant response system in the short-term post-wounding effect in Mesembryanthemum crytstallinum leaves. J Plant Physiol 165:127-137

Smirnoff N (2000) Ascorbic acid: metabolism and functions of a multifacetted molecule. Curr Opin Plant Biol 3:229-235

Smirnoff N, Pallanca JE (1996) Ascorbate metabolism in relation to oxidative stress. Biochem Soc Trans 24:472-478
Solymosi K, Martinez K, Kristóf Z, Sundqvist K, Böddi B (2005) The effect of prolonged etiolation inside the cabbage (Brassica oleracea L. cv. capitata) head and the greening of the different leaf layers. Acta Biol Szeged 49:227-228

Surówka E, Kornaś A, Miszalski Z (2009) On the role of vitamin E in Arabidopsis thaliana seedlings growing at low light intensity. In: Caporossi D, Pigozzi F, Sabatini S (eds) SFRR-E Meeting "free radicals, health and lifestyle: from cell signalling to disease prevention-SATELLITE SYMPOSIUM ON VITAMIN E", Rome, August 26-29, Proceedings of the 2009 Annual Meeting of the Society for Free Radical Research-Europe, pp 131-136

Szymańska R, Kruk J (2008a) Tocopherol content and isomers' composition in selected plant species. Plant Physiol Biochem 46:29-33

Szymańska R, Kruk J (2008b) $\gamma$-Tocopherol dominates in young leaves of runner bean (Phaseolus coccineus) under a variety of growing conditions: the possible functions of $\gamma$-tocopherol. Phytochemistry 69:2142-2148

Thordal-Christensen H, Zhang Z, Wei Y, Collinge DB (1997) Subcellular localization of $\mathrm{H}_{2} \mathrm{O}_{2}$ in plants. $\mathrm{H}_{2} \mathrm{O}_{2}$ accumulation in papillae and hypersensitive response during the barley-powdery mildew interaction. Plant J 6:1187-1194

Veljovic-Jovanovic SD, Pignocchi C, Noctor G, Foyer CH (2001) Low ascorbic acid in the $v t c-1$ mutant of arabidopsis is associated with decreased growth and intracellular redistribution of the antioxidant system. Plant Physiol 127:426-435 